\title{
Towards an African ecogender theology: A decolonial theological perspective
}

\author{
Kaunda, Chammah J \\ University of KwaZulu-Natal \\ pastorchammah@gmail.com
}

\begin{abstract}
The struggles for environmental and gender justice have challenged how theology is done in Africa. This article framed within the context of continuous search for lifegiving African Christianity, argues that a radical relational solidarity that existed between African humanity and environment in some Zambian traditional societies was grounded on ecogender principle. Thus, it seeks to probe deeper into contemporary challenge of African men's alienation from environment as a consequence of colonial quest to restructure African social order. Employing decolonial theological perspective, the article tried to reinterpret some life-giving elements from Bemba and Shila cultural heritage in order to re-conceptualize contemporary African Christian ecotheology. It is from this perspective where African ecogender theology is constructed towards transformation of African human and environment relationship.
\end{abstract}

Keywords

Environmental justice, gender justice, Bemba culture, Shila culture, Zambian traditional societies, African Christian ecotheology

\section{Introduction}

In his book, Ecological Imperialism, Alfred Crosby argues that European colonialists did not arrive in the colonies alone, but were accompanied by "a grunting, lowing, neighing, crowing, chirping, snarling, buzzing, selfreplicating and world-altering avalanche." This "world-altering avalanche"

1 Alfred W Crosby, Ecological Imperialism: The Biological Expansion of Europe, 9001900, (Cambridge: Cambridge University Press, 1986), 94. 
that slid outward from Europe dis-figured, diseased and upended traditional African social order undergirded by matrix trilogy of culture, religion and ecology as central organising principles. ${ }^{2}$ The resurgence of African $^{3}$ ecofeminist struggle against gender and ecological injustice is connected to colonialization of indigenous knowledge in Africa. This has been seen as tantamount to the shift in traditional African environmental philosophy and knowledge which was based on kindness, kith and kin relationship between human beings and environment. ${ }^{4}$

The colonial conception of environment was based on cultural injustice as they sought to replace African indigenous worldview with European concepts and categories. The colonialist did not seek to understand how African worldview functioned in relation to environmental ${ }^{5}$ conversation because of a preconceived claim to European cultural

2 If Amadiume, Reinventing Africa: Matriarchy, Religion, Culture (London: Zed Books, 1997); Oyeronke Oyewumi, The Invention of Women: Making an African Sense of Western Gender Discourse (Minneapolis: Univ. of Minnesota Press, 1997); Olabiyi B. Yai, 'Tradition and the Yorùbá Artist,' African Arts, 32/1 (1999), 32-34; Frantz Fanon, Toward the African Revolution, trans. Haakon Chevalier (New York: Grove Press, 1964). Various articles dealing with the same subject have been published in the edited book by Rosemary S Ruether. See her, Women Healing the Earth: Third World Women on Ecology, Feminism, and Religion edited by 143-160 (Maryknoll: Orbis, 1996); See especially articles by Sara C Mvududu, Mutasa T. Nyajeka and Teresia Hinga.

3 The concept 'Africa' and its adjective 'African', unless specified, refer to the people of Bantu ancestry in the Sub-Saharan continent.

4 Sofia Chirongoma, 'Motherhood and ecological conversation of mother earth,' Women in God's Image 10 \& 11, (2005): 8-12; Madipoane Masenya, 'All from the Same Source? Deconstructing a (male) Anthropocentric Reading of Job(3) through an Eco-bosadi Lens,' JTSA 137 (2010): 46-60; Madipoane Masenya, An Eco(bosadi) Reading of Psalm 127 : 3-7, 'The Earth Stories in the Psalms and the Prophets' (Sheffield : Sheffield Academic Press, 2001); Eunice Kamaraa, 'From individualism to communitarianism: Mission in caring for God's creation,' in Witnessing in the midst of suffering creation - a challenge for the Mission of the Church edited by Vischer Luksa, 135-147 (Geneva: Centre for International Reform, 2007); Jane M. Muthuki, Rethinking ecofeminism: Wangari Maathai and the Green Belt Movement in Kenya. Master's thesis (Pietermaritzburg, University of KwaZulu-Natal, 2006); Isabel A. Phiri, 'The Chisusmphi Cult: The role of women in preserving the environment'. In Women healing earth: Third World women on ecology, feminism and religion edited by Rosemary R Ruether, 161-171 (Maryknoll: Orbis Books); Oswell Rusinga and Richard Maposa, 'Traditional Religion and Natural Resources: A Reflection on the Significance of Indigenous Knowledge Systems on the utilisation of Natural Resources among the Ndau People in South-eastern Zimbabwe,' Journal of Ecology and the Natural Environment 2/9 (2010): 201-206.

5 The term 'environment' is used interchangeably with notions such as ecology, creation, nature and nonhuman nature. 
superiority. Particularly the concept of "fixity" has been described as an important feature of colonial discourse in its ideological construction and representation of African cultures and environment. ${ }^{6}$ Homi Bhabha sees "[f]ixity, as the sign of cultural/historical/racial difference in the discourse of colonialism, is a paradoxical mode of representation: it connotes rigidity and an unchanging order as well as disorder, degeneracy and daemonic repetition." The colonialist claim to cultural superiority meant that theirs was 'fluid' and 'flexible' thereby juxtaposed with African cultures which were categorized as 'fixity' or as 'permanently' trapped within 'a primitive past' and locked out of scientific modernity. The subliminal message in the concept of 'fixity' implied inability on the part of African cultures to conform to colonialist norm.

This means to a large extent that the current African eco-feminist struggle with ecological crises and its interconnectedness with exploitation of African women is historically situated within colonial epistemic injustice in which nineteenth and twentieth century European category of thought, entrenched in Enlightenment framed within an overarching patriarchal model, imposed on African people in the disguise of universal knowledge. In the aftermath of the colonization of the environment, African worlds shifted from indigenous organic conception of cosmos, to an androcentric mechanistic view of the cosmos as lifeless matter, passively obeying mechanical laws and at the disposal of human exploitation. This universal impersonator called 'colonial discourse' did not just intermingle with African indigenous knowledge systems but corrupted, distorted and disoriented them. The so-called indigenous knowledge in its current form bears a conspicuous and malicious imperial and colonial imprint of domination and white male hegemony. ${ }^{8}$

It is within this context that the following pertinent questions are raised: In what ways can African ecogender theology help African theologians to begin pioneering new analytical systems for reconstructing indigenous knowledge systems in the context of oppression of women and environment?

6 Jacques Derrida, 'Homi Bhabha the Other Question,' Screen 24 (1983): 18-36 at 18.

7 Homi K. Bhabha, The Location of Culture (New York: Routledge, 1994), 66.

8 Rajeev Bhargava, 'Overcoming the Epistemic Injustice of Colonialism,' Global Policy, 4/4 (2013): 413-417. 
Can colonial alienation of African men from the environment be classified as oppression? What contours can be developed for constructing an African ecogender theology from indigenous knowledge perspectives steeped in culture-specific paradigms? The intention of these questions is to search for ways in which African ecogender theology can function "as a major factor in destabilizing the homogenizing imperative of western scholarship in the sense that specific historical circumstances such as colonialism" contributed to the destruction of relational bond between African men and environment. The objective of constructing an African ecogender theology is to enable African women and men to understand some African present realities as continuation of colonial matrices of power.

In an attempt to respond to questions above, this article is developed in three parts. The first part frames decolonial theological approach to gender and environment in Africa. The second part utilises two case studies of African cults of nature to demonstrate that African men, like African women, were interconnected with the environment. In addition to how colonialism contributed to current alienation of African men from the environment, and created a link between African women and the environment based on mutual experiences of oppression and exploitation. The last part develops some theological contours that can undergird an African ecogender theology as a way of thinking about gender and environment.

\section{Framing decolonial theological imagination}

Colonial conquest was a ferocious attack on the essence of African humanity. It was a violent attack on matrix trilogy of culture, religion and environmental kinship, devouring the essence of their sociorelational nature. This violence did not only occur at physical, cultural, linguistic or psychological levels, but also at environmental level, reducing the environment to a lifeless machine. In the context of subduing the environment, Christianity was utilized as a mechanism of power by colonialists. This resulted in fabrication of a new social order. Thus, any theology that does not take this in consideration cannot possibly help Africans to escape the fetters of colonialism in its current manifestation.

9 Muthuki, Rethinking ecofeminism, 15. 
Decolonial theology is a struggle to conceptualize how precolonial social order functioned and find critical ways of rethinking modern African Christian experience without failing into the trap of cultural revivalism. Decolonial theology is not about reclaiming cultural past but redesigning the present by re-conceptualizing how some cultural values could have developed on their own terms through assimilation and interaction with other global cultures if they were not estranged through negative encounter with colonialism.

Decolonial theory within African theological innovations tries to reinterpret and reconceptualise some life-giving African cultural elements within contemporary African realities with a concern for liberation and emancipation of African people and environment from all forms of oppression and exploitation. ${ }^{10}$ This approach is informed by decolonial discourses articulated within the social sciences. ${ }^{11}$ The theory links contemporary global design to the continuation of colonial past. Nelson Maldonado-Torres defines decolonial thinking as process of "dismantling of relations of power and conceptions of knowledge that foment the reproduction of racial, gender, and geopolitical hierarchies that came into being or found new and more powerful forms of expression in the modern/colonial world."12 In this approach, the theologies of missionaries are primarily seen "as a denial of the God who brings freedom concretely in history"13 without uprooting people from their cultural traditions and relegating them to perpetual dehumanization. The point is that prevailing theologies in most African churches grew out of European experiences, rather than out of African experiences of God within their cultural traditions, religious past and existential realities. God was presented to

10 Chammah J. Kaunda, 'The Denial of African Agency: A Decolonial Theological Turn,' Black Theology 13/1 (2015): 73-92

11 See, Ramón Grosfoguel, 'The epistemic decolonial turn: Beyond political-economy paradigms,' Cultural Studies, 21/2-3 (2007):211-223; Nelson Maldonado-Torres, 'Cesaire's Gift and the Decolonial Turn,' Radical Philosophy Review 9/2 (2006):111-138; Sabelo J. Ndlovu-Gatsheni, 'Perhaps Decoloniality is the Answer? Critical Reflections on Development from a Decolonial Epistemic Perspective,' Africanus: Journal of Development Studies 43/2 (2013): 1-12; Walter D. Mignolo, 'Introduction: Coloniality of Power and De-Colonial Thinking,' Cultural Studies, 21/2 -3 (2007): 155 -167.

12 Maldonado-Torres, 'Cesaire's Gift and the Decolonial Turn,' 117.

13 William J. Nottingham, 'Review: Decolonizing Theology: A Caribbean Perspective by Noel Leo Erskine,' The Journal of Developing Areas 17/ 2 (1983): 286-288 at 186. 
Africans through European cultural symbols but African. Missionary Christianity is, as Kwame Nantambu points out, "a derived way of life and belief system promulgated and manipulated by Europeans for Europeans so as to facilitate and advance their religious supremacy." 14 The relational bond between human beings and environment was maintained religiously by the belief in a Supreme Being. Thus, through Bible translations into African languages, the missionaries introduced an alien concept of God that placed humanity at the apex of creation. ${ }^{15}$ The African notions of God, embedded in equality of all creation, in the kindness, kith and kinship with the environment where colonized and overthrown and missionary idea of God took a centre stage. ${ }^{16}$ Missionary idea of God today is "one of the most, if not the most, potent religious weapon in the arsenal of European supremacy to exercise their psycho-political power control over African people." ${ }^{17}$ The missionary idea of God was not based on a God who enables resistance to injustice, rather on a God who enforces docility and passivity in the face of imminent exploitation and oppression. ${ }^{18}$ This contributed to uprooting and alienation of African people from their cultures, with dire consequences as this negated their subjectivity, agency and rendered them susceptible to colonial exploitation and oppression.

By colonizing African ideas of God, the European missionaries and colonizers managed to introduce a different model of human relation to the environment. This model has continued as coloniality, a manifestation of colonial character in modern African systems, demonstrated through

14 Kwame Nantambu, Egypt \& Afrocentric geopolitics: Essays on European supremacy (Kent: Imhotep, 1996), 65.

15 Musa W. Dube, 'Consuming a Colonial Cultural Bomb Translating Badimo Into'Demons' in the Setswana Bible (Matthew 8.28-34; 15.22; 10.8),' Journal for the Study of the New Testament 21/73 (1999): 33-58.

16 Harvey Sindima, 'Community of life: Ecological Theology in African Perspective,' In Liberating Life: Contemporary Approaches in Ecological Theology edited by Charles Birch, William Eakin and Jay B. McDaniel, 137-147 (Maryknoll, New York: Orbis Books, 1990).

17 Nantambu, Egypt \& Afrocentric geopolitics, 65.

18 Pierre Mutambaka, 'Christianity and the underdevelopment of the African mind,' In Christian missionarism and the alienation of the African Mind edited by edited by Ramadan S. Belhag, Yassin A. El-Kabir, 63-69 (Tripoli, Libya: The African Society of Social Sciences, 1986); Mambo Ama Mazama, 'Afrocentricity and African Spirituality,' Journal of Black Studies 33/2 (Nov., 2002): 218-234. 
hierarchies of power, gender, ethnicity, ecological domination, theological/ knowledge production and a mis/mistaken representation of Western knowledge as universal system of thought. Underpinning decolonial theological paradigm on African cultural traditions of ecogender is based on a search for creative and innovative theological ways of critiquing the continuation colonialism which has persisted in two spheres: colonialism linked to oppression of African women and environment, and the disengagement between African men and environment. Human power over and the lack of power by environment in contemporary African societies resulted in exploitation and oppression of the environment. Decolonial theological engagement with ecogender traditions seeks to unravel the interconnectedness of coloniality of gender and environment and focuses equally on both the experiences of the oppression of African women and estrangement of African men as an dark side of modernity. Hence, decolonial theological discourse is a critical variable in investigating how missionary theology and colonial discourse stripped the primordial sacredness of African environment and destroyed African indigenous "relational quality of embodied environmental experience."19 This dislocation and disruption continues to manifest in contemporary African gender performances that are essentially unjust and unequal and in the upsurge of ecological degradation. The argument is that decolonial theology does not just challenge the oppression of African women and environment, it goes further to investigate how that connection came to be and also challenges the variable forces of oppression that form the substratum together with those that perpetuate subjugation of African people and environment. Finally, it acknowledges that "all oppressions are related and reinforce each other." 20 These oppressions and exploitations are historically situated.

19 Damayanti Banerjee and Michael Mayerfeld Bell, 'Ecogender: Locating Gender in Environmental Social Science,' Society \& Natural Resources: An International Journal 20/1(2007): 3-19 at 6-7.

20 Andy Smith, 'Ecofeminism through an Anticolonial Framework,' In Ecofeminism: Women, Culture, Nature edited by Karen J. Warren and Nisvan Erkal, 21-37 (Indiana: Indiana University Press, 1997), 21 


\section{Eco-masculinities and colonial disruption: The two rituals of nature in Zambia}

This section discusses two examples of ecogender traditions ${ }^{21}$ known as rituals of nature also called "territorial cults" 22 that demonstrate the previous interconnection between African men and the environment.

\section{Chitemene: The Bemba nature ritual}

The Bemba people are the largest ethnic group in the northern part of Zambia. They specialised in the shifting cultivation system called chitemene. This is a practice which involved cutting the trees and burning them prior to the start of rainy season (spring) and planting took place at the beginning of the rain..$^{23}$ In this worldview, chitemene was not just for food production, it had a ritual significance. It epitomised what it meant to be a Bemba man. Audrey Richard noted that ukutema (verb for chitemene) was "a man's task par excellence in the whole economic routine." 24 Traditionally, chitemene was an agricultural ritual which represented a framework through which to view the social development of Bemba masculinities. In the Bemba thought ubupalume (warriorism) was essentially associated with the felling of the branches of the trees. When men climbed the trees and started lopping with dexterousness that was the measure of manliness.

21 The process of transition that I have explained in this part parallels the process of transition that has taken place with the Ndembu ritual of Hunting. This ritual was also a religious ritual which defined Ndembu masculinities in a similar way that chitemene and fishing did to the Bemba and Shila men. It was also the basis for male interrelation with the environment. See Victor Turner, Schism and Continuity in an African Society: A Study of Ndembu Village Life (Manchester: Manchester University Press, 1957); Victor Turner, The forest of symbols: Aspects of Ndembu ritual (Ithaca, N.Y.: Cornell University Press, 1967); James A. Pritchett, The Lunda-Ndembu: Style, Change, and Social Transformation in South Central Africa (Wisconsin: University of Wisconsin Press, 2001).

22 Matthew J. Schoffeleers (ed.), Guardians of the Land, Essays on Central African Territorial cults (Gweru: Mambo Press, 1999).

23 For a detailed discussion on chitemene and Bemba masculinities see Audrey Isabel Richard, Land, Labour and Diet in Northern Rhodesia: An Economic Study of the Bemba Tribe (London: University of Oxford Press, 1939) and Peter Joy, 'The Crisis of Farming Systems in Luapula Province, Zambia,' Nordic Journal of African Studies 2/2 (1993): 118-140; Alistair J. Sutherland, 'The Gender Factor and Technology Options for Zambia's Subsistence Farming Systems,' Gender issues in farming systems research and extension (1988): 389-406.

24 Richard, Land, 289. 
Henrietta Moore and Megan Vaughan noted that in precolonial Bemba self-representation, chitemene was a symbol of masculinity, ethnic autonomy and link with spiritual reality. ${ }^{25}$ The forest was synonymous with spirituality. There, the presence of ancestors and ancestresses was experienced. Ukusaila (pollarding the branches of trees), quintessential male activities, was the most dangerous of all activities. The men were required to climb the trees and cut its branches from the top and the agility displayed in reaching the topmost branches of the tree and skilfully lop them off was a measure of masculinity but also spiritual blessings from ancestors and ancestresses who gave them protection. The felling of branches was symbolically seen as subduing and establishing hegemony over rivals.

The Chitemene ritual connected Bemba men with the environment, ancestors, ancestresses and natural spirits that inhibited specific woodland groves. These spiritual forces were the guardians of the environment and by paying homage to them Bemba people believed that they could receive protection and blessings during ukutema. The prayers were offered to the spirits of ancestors and ancestresses of the woodland at the beginning of ukutema season. The rule of chitemene demanded that the trees not be obliterated (ukubungula) but rather pruned or "pollarded" (ukusaila). ${ }^{26}$ The burning was meant to provisionally provide ash-fertilizer for the soil. The crops were grown around the base of trimmed trunks which remained standing and started regenerating. The women only joined men in process of systematically piling the lopped branches (ukukulula fibula) into a form of chitemene garden which was later burned in readiness for plantation.

While this method was perceived as disastrous in terms of deforestation and depletion because of European prejudice against African traditional agricultural methods, early anthropologists such as Audrey Richard and

25 Henrietta Moore and Megan Vaughan have made an excellent linked between gender and chitemene among the Bemba people demonstrating that the breakdown in kinship begun with the cheap labour migration of Bemba men. See, their Cutting Down Trees: Gender, Nutrition, and Agricultural Change in the Northern Province of Zambia, 18901990 (Portsmouth, NH.: Heinemann, 1994), see also Melissa Leach and Cathy Green who have made a concise summary of Moore and Vaughan's argument. See, their, 'Gender and Environmental History: From Representations of Women and Nature to Gender Analysis of Ecology and Politics,' Environment and History 3/3 (1997): 343-370.

26 Richard, Land, 19; Joy, 'The Crisis of Farming Systems'. 
Robert Baldwin, and current anthropologists such as Henrietta Moore, Megan Vaughan, Peter Joy and Bruce Campbell argue that Europeans, in over 40 years of occupation of the Northern part of Zambia, did not find any better method of cultivating crops in this particular area (at least up to the time Richard was writing in 1939). ${ }^{27}$ Paul Zeleza affirms that "far from being a wasteful method of cultivation, chitemene as a set of agricultural practices and strategies was remarkably diverse, variable, adaptable, resilient, environmentally sound and productive." ${ }^{28}$ On the one hand, scholars have argued that chitemene was a resourceful system for providing Bemba people with seasonal production of high quality cereals and vegetables in regions of acidic and heavily leached soils. ${ }^{29}$ On the other hand, it is also important to note that the method was viable in precolonial times because the woodlands were in abundance and villages were small. Nevertheless, before the Bemba people could develop another technique embedded in relational bondedness with the environment the European colonialist disrupted the process. They attributed ukutema to the 'laziness'.

But the chief reason for colonialist condemnation of chitemene was based on the search to establish control over Bemba chiefly territories from the 1890 's, centred on the activities of the British South Africa Company (BSAC) and of the Roman Catholic Church Missions. The colonial administrators sought to have control over the movements of the Bemba people, as during ukutema season (which started somewhere in April and ended in August or September) families went to live in mitanda (temporal shelters or seasonal chitemene huts). The first attempts to intervene in chitemene were in the context of hut tax collections which intended to restrict the people's movements. Other measures were enforced to stop seasonallymobile settlement patterns which were required by chitemene. For instance, imitanda were abolished. James Pritchett notes that "to ensure that the tax accomplished its objective of producing a steady stream of cheap labour,

27 Richard, Land, 19; Robert E. Baldwin, Economic Development and Export Growth: A Study of Northern Rhodesia, 1920-1960 (Berkeley: University of California Press, 1966).

28 Paul Tiyambe Zeleza, 'Review: Cutting Down Trees: Gender, Nutrition, and Agricultural Change in the Northern Province of Zambia,' The International Journal of African Historical Studies, 28/2 (1995): 404-406 at 405. See also Bruce Campbell (ed.), The Miombo in Transition: Woodlands and Welfare in Africa (Bogor, Indonesia: Centre for International Forestry Research, 1996).

29 Joy, 'The Crisis of Farming Systems,' 128. 
the BSAC eliminated alternative methods by which Africans could acquire cash." ${ }^{0}$ Thus, chitemene was finally abolished in 1906 as a means "to facilitate the control ... and the collection of hut tax". ${ }^{31}$

Yet, it never completely stopped. It was only severely curtailed in the 1930's onwards when over 40 to 70 percent of taxable men were forced into labour migration to work in the mines in the Copper belt (Zambia), South Africa and Zimbabwe. ${ }^{32}$ This seems to have begun the process of disengaging relational bond between Bemba men and the environment. Richards perceived this process of integrating Bemba men into the cash economy as engendering a breakdown in the kinship relations with which chitemene was intimately intertwined. The Bemba food production system was also perceived as breaking down at the same time when men were forced to migrate from their villages.

In the face of male absenteeism women turned to semi-permanent gardens and gathering activities linked to fallow cycles. Thus, women began to develop a new bond with the environment based on suffering at the same time as men were being estranged from environmental kinship. This resulted in Bemba food insecurity as the importance of chitemene practice required male labour to keep the "system running and this gave women some moral leverage over their husbands." ${ }^{33}$ Evidently, the connection that some contemporary African ecofeminists ${ }^{34}$ have made between women and

30 Pritchett, The Lunda-Ndembu, 34.

31 Henry S. Meebelo, Reaction to Colonialism: A Prelude to the Politics of Independence in Northern Zambia, 1893-1939 (Manchester: Manchester University Press, 1971), 105.

32 Moore and Vaughan, Cutting Down Trees, 148.

33 Moore and Vaughan, Cutting Down Trees, 94.

34 See for example, Lilian Cheelo Siwila, who develops her so called 'transformative approach to dialogue on African ecofeminism' on 99.9 percent of arguments from other parts of the world with less than 0.1 percent from African scholars. What kind of African ecofeminism is that? I think a point is missed here, something can only be regarded as African if it expresses the originality and essence of African worldview in its diverse manifestations as tradition and contemporary. See her, "Tracing the ecological footprints of our foremothers': Towards an African feminist approach to women's connectedness with nature,' Studia Historiae Ecclesiasticae 40/2 (2014): 131-147. Phiri, also in 'The Chisumphi cult,' reveals a level of gender bias. She rightly confirms Barrett and Browne's [see, Hazel Barrett and Angela Browne, 'Gender, Environment and Development in Sub-Sahara Africa,' In People and Environment in Africa edited by Binns Tony, 32-34 (Chichester: John Wiley and Sons Ltd, 1995)] research that links women and environment. But the fact that Phiri does not openly acknowledge is that 
environmental oppression was finally established. ${ }^{35}$ The colonial situation both alienated Bemba men from their environment and forced Bemba women to evolve new methods of relating with the environment. ${ }^{36}$

\section{The Ubutwa: Shila nature cult}

The second case study is based on Ubutwa, a cult of nature that functioned in the precolonial and early colonial period in Northeast Zambia. The cult was active in the northern and western shore of Lake Tanganyika, south of Lake Mweru, along the Luapula River, around Lake Bangweulu, the swamps, and along the lower Chambeshi River. ${ }^{37}$ According to Mwelwa Musambachime the term Ubutwa is rooted in the Bemba-related languages, widely spoken in Eastern and North East Zambia. It means to be "sharp...

all the four linking factors she outlines can be equally applied to African men: Firstly, women as providers for their homes and families, interact with nature for domestic production of medicines, relish, firewood, herbs etc. Secondly, women are linked to nature for income purposes. Thirdly, women have always been involved in ecological preservation. Fourthly, women are linked to the ecosystem through agricultural activities.

35 Unfortunately, some African ecofeminists have made the link between oppression of women and environment without seriously investigating historical circumstances which engendered it.

36 In the research that Celia Nyamweru did among the Mijikendi of Kenya, she discovered that in this ethnic group, the general claim by some ecofeminists that women are friendlier to the environment is based on essentialist assumption, as both men and women are equally connected to their environment. This is a caution to some African ecofeminists who have uncritically followed meta-narrative to essentialise or manipulate certain cults to promote only the interests of women without acknowledging the equal contribution of both men and women. See, 'Women and the Sacred Groves in Coastal Kenya: A Contribution to the Ecofeminist Debate,' In Ecofeminism \& Globalization: Exploring Culture, Context, and Religion, edited by Heather Eaton and Lois Ann Lorentzen, 41-56 (Lanham, Md.: Rowman \& Littlefield, 2003).

37 The cult has not received adequate attention from scholars and there are few contemporary Zambians who know about this society. David Gordon feels that the reason for such scant attention could be associated with the early missionary condemnation. See his, 'From Sacred Ownership to Colonial Commons: Water Tenure Systems in Central Africa,' In A History of Water: The World of Water. Volume III, edited by Terje Tvedt and Terje Oestigaard, 18-37 (London and New York: I.B. Tauris, 2006). For detailed discussed of Ubutwa see, Mwelwa C. Musambachime, 'The Ubutwa Society in Eastern Shaba and Northeast Zambia to 1920,' The International Journal of African Historical Studies, 27/1 (1994), 77-99. Dugald Campbell, 'A Few Notes on Butwa: An African Secret Society,' Man 14 (1914), 76-81; Dugald Campbell, In the Heart of Bantuland: A Record of Twenty-nine Years' Pioneering in Central Africa among the Bantu Peoples (London: Seeley, Service \& Co., 1922). 
or to pound something using a mortar and pestle." ${ }^{38}$ The cult is believed to have originated from Abatwa people (the 'Pygmies') and spread to the Bwilile people (also known as Mbolela pano - I rot right here) of Luapula. The cult was later adopted and spread to the Shila people, a kingless sect of the earliest Bemba people who arrived in Zambia before the coming of great kings (Chitimukulu) of the present Bemba people discussed above. ${ }^{39}$ The name Shila is derived from taboos (imishila) connected with hunting and fishing which was the speciality of this ethnic group.

It was among this ethnic group that Ubutwa was popularised. The cult was structured in lodges of magicians at regional level headed equally by both Nangulu (a female with the powers to manipulate natural spirits) and Shingulu (a male counterpart). It was based on gender equality as these leaders had also ten assistants - five women and five men - who were knowledgeable in Ubutwa philosophy and served as co-guardians of the land. ${ }^{40}$ This organisation created a sacred space for the selection of Shila rulers and the sanctioning of their control over natural resources. ${ }^{41}$ It also enabled the Shila to integrate the environment within their sociocultural relationships. They had a system of shrines in sacred places such as waterfalls and springs where the ancestors and natural spirits were paid homage. These rituals were believed to be important for the wellbeing of both the people and the environment. The failure to conduct such rituals or a breach in taboos, such as fishing during breeding (taboo) seasons, would lead to natural disasters. The cult was significant in enabling people to realise that they could not expect more from the environment than their investment of love, nurturing and protection.

Therefore, among the Shila, it was the water and its produce (fish) that needed nurturing, tendering and management. The most important rituals and shrines revolved around the Luapula River and Lake Mweru. ${ }^{42}$ The

38 Musambachime, 'The Ubutwa Society,' 83-84.

39 A detailed history of Shila is discussed in Mwelwa C. Musambachime, 'History of the Shila People,' MA. Thesis, (Wisconsin, University of Wisconsin, 1974).

40 Musambachime, 'The Ubutwa Society,' 79.

41 Gordon, 'From Sacred Ownership to Colonial Commons,' Musambachime, 'The Ubutwa Society,' Campbell, 'A Few Notes on Butwa.'

42 For more discussion about the history of conquest of Shila people by Mwata Kazembe (King of which is not the focus of this article see, Ian George Cunnison The Luapula 
Shila believed that they were the sacred owners of their particular land and lake which meant that for healthy relationships between women and men and their environment they needed to continue offering gifts and paying homage to the ancestors and nature spirits. Sometimes they visited the graveyards of their ancestors and offered beer and impemba (powdered white clay). Prayer helped them to an ethics of responsibility in their fishing methods and provided success in fishing. It also facilitated safety of the fishers and gave them some of spiritual powers to control their fishing territories. ${ }^{43}$ The sacred owners of the lagoons prohibited fishing (ukushilika isabi) for several months of the year during breeding season. It was also the sacred owners who had the power to ukushilula imimana (unlocking the fisheries). Before unlocking the fisheries, the annual prayers were offered to the ancestors and the natural spirits.

Mulundu, a leader of abena koswe (the rat clan) and sacred owner, made a pilgrimage to an ancient shrine where the masombwe relic was kept by the head of another Shila clan, abena mfula (the rain clan). The masombwe was a medium of communication with the spiritual world and only abena mfula had the priesthood right as guardians to use the sacred relic. Early in the day Mulundu went there to pray and make offerings to ensure a prosperous fishing season. ${ }^{44}$ The keepers of the masombwe shrine would reveal to him the mind of the ancestors. There was power sharing and mutual accountability in the way the environment was managed. It was only after the guardians (descendants of abena koswe) had discerned a clear message from ancestors giving greenlight to open the fisheries, could Mulunda physically unlock the fisheries. Otherwise, he had not power to unlock them. The same applies to the guardians. While they were the spiritual ears and eyes of the community, they had no right to physically unlock the fisheries as this was leadership prerogative of the descendants

Peoples of Northern Rhodesia: Custom and History in Tribal Politics (New York: The Humanities Press, 1959); David Gordon, 'Technological change and economies of scale in the history of Mweru-Luapula's fishery (Zambia and Democratic Republic of Congo),' FAO Fisheries Technical Paper 2 (2003): 165-178. David M. Gordon, Nachituti's Gift: Economy, Society, and Environment in Central Africa (Madison: University of Wisconsin Press, 2006).

43 Gordon, 'From Sacred Ownership to Colonial Commons.'

44 See for example, Cunnison, The Luapula Peoples of Northern Rhodesia; Gordon, From Sacred Ownership to Colonial Commons; Gordon, 'Technological change.' 
of abena mfula. In this way, balance in leadership was maintained and any breach was deemed taboo that could have negative consequences for the whole community.

Once the guardians had discerned the message from the ancestors, it became the responsibility of Mulundu together with the whole community to go to the river where he speared the first fish. Then banamayo baaula utumpundu (the women ululate) and the fisheries were declared unlocked. It is clear here that both women and men were involved and interconnected with the environment, which was not perceived as a self-sufficient entity on which human beings were to impose themselves but as a family member who took care of human beings and vice versa. This has been well articulated by Matthew Schoffeleers in the introductory chapter to Guardians of the Land, in which he asserted "reduced to their core, territorial cults are based on the idea that the satisfactory functioning of the environment depends not only on the directly ecological activity of man [sic] but also on the satisfactory functioning of society as a whole." ${ }^{35}$

Unfortunately, the missionaries and administrative officials had a prejudice against Ubutwa and did not invest in studying the cult in order to get firsthand information of its organisation and functions. Dugald Campbell, the first to write an article on Ubutwa, did not engage with the cult empirically but relied on secondary information from a paper written for him in a local "language by an ex-witch-doctor (sic)." 46 The beginning of colonial ecopolitics redefined the way Shila people, men in particular, were to relate with the environment. The people were no longer living in harmony with the environment. Colonialists also placed under the jurisdiction of science and western capitalism.

The colonial administrator seized Mweru-Luapula and attempted to restrict Shila fishers so as to recruit them for cheap migration labour in

45 Matthew Schoffeleers, 'Introduction,' In Guardians of the Land, Essays on Central African Territorial cults, edited by Matthew J. Schoffeleers, 1-46 (Gweru: Mambo Press, 1999), 41.

46 Dugald Campbell, 'A Few Notes on Butwa,'78, see also Musambachime's critique of Campbell on secondary use of information to critique an organisation he had not direct contact. See, Musambachime, 'The Ubutwa Society,' 98. In fact he was among the missionaries that banned Ubutwa practice in Mambilima where he was missionary. See, Campbell, 'A Few Notes on Butwa,' 79; also In the Heart of Bantuland, 161. 
the mines or as fishermen for white male fishing industries. The colonial capitalist economy relied on cheap migration labour. Almost all Shila men of taxable age were extracted from their villages to work in the mines within the country and across the borders in South Africa and Zimbabwe as also noted in the context of chitemene above. To ensure that they were recruitable, hut tax was imposed that required each African male to pay yearly without fail and the district officials took annual tours to ensure payment was made. In addition, the missionaries' condemnation of Ubutwa as immoral ritual practice, aided colonial administrators to engage in a persecuting campaign against the members of Ubutwa. Ubutwa declined around the 1920's. Thus the ecological balance that the cult promoted was completely transformed as women were left alone to seek for new ways of connecting with the environment as men continued to be disengaged from the environment.

The two case studies demonstrate that both men and women had mutual relationship with the environment in the precolonial times. This kinship was fractured during colonial period as African were integrated into cash economic. Can we not consider alienation of African men from environment as another form of oppression (or at least second level oppression $\left.^{47}\right)$ ? The following section is an attempt to glean some life-giving values from precolonial ecogender social organisation of the Bemba and Shila people for constructing an African ecogender theology.

\section{Towards an African Ecogender Theology}

A safer way to start enunciating African ecogender theology is by acknowledging that an African cultural past can no longer be seen as an infallible or authoritative guardian or guide to the future but a beacon of wisdom from which African Christians can draw strength and energy to forge new directions in the struggle for gender and environment wholeness. In an endeavour to open a discussion in this direction, I utilize an African theological lens to develop three fundamental African philosophical

47 This is an affirmation that African women continue to suffer oppression more than men. 
principles undergirding Chitemene and Ubutwa as points of departure for constructing an African ecogender theology as follows:

The first fundamental African philosophical principle emerging from the two case studies above is based on the conviction of the harmony of being. Both the Bemba and Shila believed in the common origin of all beings that conferred on them common essence and ensured the fundamental unity of their existence. ${ }^{48}$ This is a theology of oneness of God's creation. The African ecogender theology will focus on the search for attainment of equal partnership of all beings. The incarnation epitomises this kind of relationship, for in Jesus was found an intricate balance between the Creature (humanity) and the Creator (divinity). These two aspects were neither mixed nor confused. Jesus was not a dual personality but a reconciliation of two distinctive natures. This is a symbolic reconciliation of "all things, whether things on earth or things in heaven, by making peace through his blood, shed on the cross." ${ }^{\prime \prime}$ Through the incarnation, Jesus himself becomes an inseparable entity to creation. In this way, Jesus and all human beings are not separate entities from the environment, "they are nature itself seeking fullness in the actuality of present life." ${ }^{50}$ This reconciliation is the essence of Christian oneness with all things. Saint Paul writes, "There is neither Jew nor Gentile, neither slave nor free, nor is there male and female, [neither human nor nonhuman creation, neither God nor creation] for...all one in Christ Jesus." ${ }^{51}$ Jesus is the unifying principle of all things. Oneness of being does not mean sameness where the other ceases to be distinctive but involves the acknowledgment, acceptance and appreciation of the difference. African ecogender theology is grounded in the nonexistence of dualism in creation. All creation is woven by God into a single fabric of life, a web of life characterized by interdependence of equals.

48 Sindima, 'Community of life,' 145.

49 Colossians 1:20. All the Scripture quotations in this article are from the New International Version (NIV).

50 Sindima, 'Community of life,' 145.

51 Galatians 3:28 (NIV). 
The second fundamental African philosophical principle is grounded in the union of environment and human intellect. ${ }^{52}$ As demonstrated above, in the Bemba and Shila worldviews the environment was one of the key social organising principles for through the environment interrelated relationships - God (including all spiritual forces), human (including ancestors and those yet to be born), and nonhuman creation - were articulated. John Mbiti makes the following observation:

According to African people, man (sic) lives in a religious universe, so that natural phenomena and objects [including human beings] are intimately associated with God... man's (sic) understanding of God is strongly coloured by the universe of which man is himself (sic) a part. Man (sic) sees in the universe not only the imprint but the reflection of God; and whether that image is marred or clearly focused and defined, it is nevertheless an image of God, the only image known in traditional African societies. ${ }^{53}$

The environment is a place where human intellect and creation harmonises in order to articulate what it means to be a community of created beings. It is a site of the immanent-transcendent presence of God. In short, the African model of producing knowledge requires intertwinement of human intellect with the environment, resulting in the materialization of ideas. This means that both human intellect and environment should influence each other in this process. African ecogender theology will function within this indivisible human intellect-environment paradigm of creating knowledge and experiencing life. The biblical tradition is replete with the interpretation of a wisdom that is entrenched in the environment. For example, there are passages that show how the environment demonstrates the loving and caring heart of $\mathrm{God}^{54}$, others reveal that God's wisdom is entrenched in the environment ${ }^{55}$ and still others show that the environment

52 Victor Turner, The Ritual Process: Structure and Anti-structure (Ithaca, N.Y.: Cornell Univ. Press, 1969), 26.

53 John S. Mbiti, African Religions and Philosophy, second revised and enlarged edition (Oxford: Heinemann Education Publishers, 1990), 48.

54 Matthew 6:28-32 (NIV).

55 Proverbs 8:22-31(NIV). 
is embodied with principles of life and conduct. ${ }^{56}$ In fact, most of the parables of Jesus are derived from the environment "of the world of a firstcentury agrarian society, a world of villages and small urban towns, of aristocrats and peasants, of agriculture, of landlords and tenants, of sowing and harvesting, of fishers, shepherds and labourers." ${ }^{57}$ There is a need to relearn how to articulate life in dialogue with the environment by finding an intricate balance between human intellect and the environment. This is what will distinguish African ecogender theology from other contemporary ecological paradigms. In this way, African ecogender theology has the potential for contributing to the transformation of the present relational reality by deliberately creating a balanced community of human beings and the environment "that would integrate intuitive, spiritual, and rational forms of knowledge, embracing both science and [faith] insofar as they enable us to transform the nature-culture distinction and to envision and create a free, ecological society." ${ }^{38}$

The third fundamental African philosophical principle is a clear consciousness that God is a member of the community of life. The community is called a community of life because God is believed to be an ultimate source of its origin, its life, and the very life that is present in the intricacies of the community. The Bemba and Shila people were constantly aware of the presence of God with them through the ancestors/ancestresses and natural spirits that mediated between the environment-human beings and God. This could be seen not just in constant consultation with these spiritual realities but also in the names they gave their children that described the attributes of God. Sindima highlights that "a community of life emphasizes being-together for the purpose of allowing life to flow and for the purpose of creating possibilities for achieving umuntu." ${ }^{59}$ Therefore, African ecogender theology will be embedded in the radical awareness of the presence of the Holy Spirit in creation. Jesus was called "Immanuel"

56 Proverbs 6:6-11; Proverbs 30:24-28 (NIV).

57 Dieter Reinstorf and Andries van Aarde, 'Reflections on Jesus' parables as metaphorical stories past and present,' HTS 58/2 (2002): 721-745 at 730.

58 King in Susan Rakoczy, In her Name: Women Doing Theology (Pietermaritzburg: Cluster Publication, 2004), 314.

59 Sindima, 'Community of life,'145. 
which means "God with us". ${ }^{60}$ All creation shares an intimate relationship in the web of life with God and one another. God is not above creation but through the Holy Spirit is within creation and with creation as an expression of unconditional love. Nyajeka echoes the assertion of Sindima by stressing that in an African world-view of life, there is "an intricately bonded web of relationality in which the circle as a shape can be said to accurately symbolize" the unity of existence of all creation. In this understanding, there is no "theirs;" everything is conceived in collected "we." ${ }^{1}$ Hence, African ecogender theology will stress a "life-centred" concept of creation in search to create a community of wholeness, of justice, of equality, of respect, and of unconditional love.

\section{Conclusion}

To summarize the foregoing discussion, I have firstly argued that a traditional African understanding of the relationship between human beings and nature was based on kindness, kith and kin. Secondly, through two case studies of rituals that expressed human relational bondedness with environment from the Bemba and Shila people of Zambia, I have shown how missionaries and colonialism alienated some Zambia men from the environment and forced women to develop new models of relating with the environment, grounded in the mutual experiences of injustice. Thirdly, I have used African theological lens to extract three foundational African philosophical principles to construct some contours for African ecogender theology.

\section{Bibliography}

Amadiume, I. Reinventing Africa: Matriarchy, Religion, Culture (London: Zed Books, 1997).

Arnfred, S. Sexuality and Gender Politics in Mozambique: Rethinking

Gender in Africa (Suffolk: James Currey, 2011).

60 Matthew 1:23 (NIV).

61 Nyajeka, 'Shona Women,' 139. 
Baldwin, RE. Economic Development and Export Growth: A Study of Northern Rhodesia, 1920-1960 (Berkeley: University of California Press, 1966).

Banerjee, D. and Michael MB. "Ecogender: Locating Gender in Environmental Social Science," Society \& Natural Resources: An International Journal 20/1(2007): 3-19.

Barrett, $\mathrm{H}$ and Browne, A. "Gender, Environment and Development in Sub-Sahara Africa," In People and Environment in Africa edited by Tony, B., 32 - 34 (Chichester: John Wiley and Sons Ltd, 1995).

Bhabha, HK. The Location of Culture (New York: Routledge, 1994).

Bhargava, R. "Overcoming the Epistemic Injustice of Colonialism," Global Policy, 4/4 (2013): 413-417.

Campbell, B. (ed.). The Miombo in Transition: Woodlands and Welfare in Africa (Bogor, Indonesia: Center for International Forestry Research, 1996).

Campbell, D. “A Few Notes on Butwa: An African Secret Society," Man 14 (1914): 76-8.

Campbell, D. In the Heart of Bantuland: A Record of Twenty-nine Years' Pioneering in Central Africa among the Bantu Peoples (London: Seeley, Service \& Co., 1922).

Chirongoma, S. "Motherhood and ecological conversation of mother earth," Women in God's Image 10 \& 11 (2005): 8-12.

Crosby, AW. Ecological Imperialism: The Biological Expansion of Europe, 900-1900, (Cambridge: Cambridge University Press, 1986).

Cunnison, IG. The Luapula Peoples of Northern Rhodesia: Custom and History in Tribal Politics (New York: The Humanities Press, 1959).

Daneel, ML. "The Liberation of Creation: African Traditional Religions and Independent Church Perspective," Missionalia 19/2 (August1991): 99-121.

Derrida, J. “Homi Bhabha the Other Question,” Screen 24 (1983): 18-36. 
Dube, MW. "Consuming a Colonial Cultural Bomb Translating Badimo Into 'Demons' in the Setswana Bible (Matthew 8.28-34; 15.22; 10.8)," Journal for the Study of the New Testament 21/73 (1999): 33-58.

Gordon, D. "From Sacred Ownership to Colonial Commons: Water Tenure Systems in Central Africa," In A History of Water: The World of Water. Volume III, edited by Tvedt, T. and T. Oestigaard, 18-37 (London and New York: I.B. Tauris, 2006).

Gordon, DM. “Technological change and economies of scale in the history of Mweru-Luapula's fishery (Zambia and Democratic Republic of Congo)," FAO Fisheries Technical Paper 2 (2003): 165-178.

Gordon, DM. Nachituti's Gift: Economy, Society, and Environment in Central Africa (Madison: University of Wisconsin Press, 2006).

Grosfoguel, R. "The epistemic decolonial turn: Beyond political-economy paradigms," Cultural Studies, 21(2-3 (2007): 211-223.

Hinga, T. "The Kikuyu Theology of Land and Environmental Justice” in Women Healing Earth: Third World Women on Ecology edited by Ruether, RR., 172-182 (Maryknoll: Orbis Publishers 1996).

Joy, P. "The Crisis of Farming Systems in Luapula Province, Zambia," Nordic Journal of African Studies 2/2 (1993): 118-140.

Kamaraa, E. "From individualism to communitarianism: Mission in caring for God's creation." In Witnessing in the midst of suffering creation - a challenge for the Mission of the Church, edited by Luksa, V., 135-147 (Geneva: Centre for International Reform, 2007).

Kaunda, CJ. “The Denial of African Agency: A Decolonial Theological Turn," Black Theology 13/1 (2015): 73-92

Leach. M. and C. Green. "Gender and Environmental History: From Representations of Women and Nature to Gender Analysis of Ecology and Politics," Environment and History 3/3 (1997): 343-370.

Maldonado-Torres, N. "Cesaire's Gift and the Decolonial Turn," Radical Philosophy Review 9/2 (2006):111-138. 
Masenya, M. "All from the Same Source? Deconstructing a (male) Anthropocentric Reading of Job(3) through an Eco-bosadi Lens," JTSA 137 (2010): 46-60;

Masenya, M. Eco(bosadi) Reading of Psalm 127 : 3-7, "The Earth Stories in the Psalms and the Prophets" (Sheffield : Sheffield Academic Press, 2001).

Mazama, MA. "Afrocentricity and African Spirituality," Journal of Black Studies 33/2 (Nov., 2002): 218-234.

Mbiti, JS. African Religions and Philosophy, second revised and enlarged edition (Oxford: Heinemann Education Publishers, 1990).

Meebelo, HS. Reaction to Colonialism: A Prelude to the Politics of Independence in Northern Zambia, 1893-1939 (Manchester: Manchester University Press, 1971).

Memmi, A. The Colonizer and the Colonized (Boston, MA: Beacon Press, 1967) [original French edition, with a prologue by Jean-Paul Sartre, 1957].

Mignolo, WD. "Introduction: Coloniality of Power and De-Colonial Thinking," Cultural Studies, 21/2 -3 (2007): 155 -167.

Moore, H. and M. Vaughan. Cutting Down Trees: Gender, Nutrition, and Agricultural Change in the Northern Province of Zambia, 1890-1990 (Portsmouth, NH.: Heinemann, 1994).

Musambachime, MC. "The Ubutwa Society in Eastern Shaba and Northeast Zambia to 1920," International Journal of African Historical Studies, 27/1 (1994): 77-99.

Musambachime, MC. "History of the Shila People," MA. Thesis (Wisconsin, University of Wisconsin, 1974).

Mutambaka, P. "Christianity and the underdevelopment of the African mind," In Christian missionarism and the alienation of the African Mind edited by Belhag, RS. and YA. El-Kabir, 63-69 (Tripoli, Libya: The African Society of Social Sciences, 1986). 
Muthuki, JM. "Rethinking ecofeminism: Wangari Maathai and the Green Belt Movement in Kenya," Master's thesis, (Pietermaritzburg, University of KwaZulu-Natal, 2006).

Mvududu, SC. "Revising Traditional Management of the Indigenous Woodlands," In Women Healing the Earth: Third World Women on Ecology, Feminism, and Religion edited by Ruether, RR. 143-160 (Maryknoll: Orbis, 1996).

Nantambu, K. Egypt \& Afrocentric geopolitics: Essays on European supremacy (Kent: Imhotep, 1996).

Ndlovu-Gatsheni, SJ. "Perhaps Decoloniality is the Answer? Critical Reflections on Development from a Decolonial Epistemic Perspective," Africanus: Journal of Development Studies 43/2 (2013): 1-12.

Nottingham, WJ. "Review: Decolonizing Theology: A Caribbean Perspective by Noel Leo Erskine," The Journal of Developing Areas 17/ 2 (1983): 286-288.

Nyajeka, TM. "Shona Women and the Mutupo Principle" In Women Healing the Earth: Third World Women on Ecology, Feminism, and Religion edited by Ruether, RR. 135-142 (Maryknoll: Orbis, 1996).

Nyamweru, C. "Women and the Sacred Groves in Coastal Kenya:

A Contribution to the Ecofeminist Debate," In Ecofeminism \& Globalization: Exploring Culture, Context, and Religion, edited by Eaton, $\mathrm{H}$ and LA. Lorentzen, 41-56 (Lanham, Md.: Rowman \& Littlefield, 2003).

Oyewumi, O. The Invention of Women: Making an African Sense of Western Gender Discourse (Minneapolis: Univ. of Minnesota Press, 1997).

Phiri, IA. "The Chisumphi cult: The role of women in preserving the environment," In Women Healing the Earth: Third World Women on Ecology, Feminism, and Religion edited by Ruether, RR., 63-105 (Maryknoll: Orbis, 1996).

Pritchett, JA. The Lunda-Ndembu: Style, Change, and Social Transformation in South Central Africa (Wisconsin: University of Wisconsin Press, 2001). 
Rakoczy, S. In her Name: Women Doing Theology (Pietermaritzburg: Cluster Publication, 2004).

Reinstorf, D. and A. van Aarde. "Reflections on Jesus' parables as metaphorical stories past and present," HTS 58/2 (2002): 721-745.

Richard, AI. Land, Labour and Diet in Northern Rhodesia: An Economic Study of the Bemba Tribe (London: University of Oxford Press, 1939).

Rusinga, $\mathrm{O}$ and $\mathrm{R}$ Maposa. "Traditional religion and ritual for resources: A reflection on the significance of indigenous knowledge systems for the utilisation of the natural resources among the Ndau People in South-East Zimbabwe," Journal of Ecology and the Natural Environment 2/9 (2010): 201-206.

Schoffeleers, MJ. "Introduction” In Guardians of the Land, Essays on Central African Territorial cults, edited by Schoffeleers, MJ. 1-46 (Gweru: Mambo Press, 1999).

Schoffeleers, MJ. (ed.), Guardians of the Land, Essays on Central African Territorial cults (Gweru: Mambo Press, 1999).

Sindima, H. "Community of life: Ecological Theology in African Perspective," In Liberating Life: Contemporary Approaches in Ecological Theology edited by Birch, C, W. Eakin and JB. McDaniel, 137-147 (Maryknoll, New York: Orbis Books, 1990).

Siwila, LC. “'Tracing the ecological footprints of our foremothers': Towards an African feminist approach to women's connectedness with nature," Studia Historiae Ecclesiasticae 40/2 (2014): 131-147.

Smith, A. "Ecofeminism through an Anticolonial Framework." In Ecofeminism: Women, Culture, Nature edited by Warren, KJ., and N. Erkal, 21-37 (Indiana: Indiana University Press, 1997).

Sutherland, AJ. "The Gender Factor and Technology Options for Zambia's Subsistence Farming Systems," Gender issues in farming systems research and extension (1988): 389-406.

Turner, V. Schism and Continuity in an African Society: A Study of Ndembu Village Life (Manchester: Manchester University Press, 1957). 
Turner, V. The forest of symbols: Aspects of Ndembu ritual (Ithaca, N.Y.:

Cornell University Press, 1967).

Turner, V. The Ritual Process: Structure and Anti-structure (Ithaca, N.Y.:

Cornell Univ. Press, 1969).

Yai, OB. “Tradition and the Yorùbá Artist," African Arts, 32/1(1999): 32-34.

Zeleza, PT. "Review: Cutting Down Trees: Gender, Nutrition, and Agricultural Change in the Northern Province of Zambia," The International Journal of African Historical Studies, 28, No. 2 (1995): 404-406. 